\title{
A sensitive liquid chromatography/tandem mass spectrometry method for the determination of natural and synthetic steroid estrogens in seawater and marine biota, with a focus on proposed Water Framework Directive Environmental Quality Standards
}

\author{
Jenny M. Ronan ${ }^{1 *}$ and Brendan $\mathrm{McHugh}^{2}$ \\ ${ }^{1}$ School of Natural Sciences, University of Dublin, Trinity College, Dublin, 2, Ireland, \\ ${ }^{2}$ The Marine Institute, Rinville, Oranmore, Co. Galway, Ireland,
}

RATIONALE: Trace levels of natural and synthetic steroid estrogens estrone (E1), 17b-estradiol (E2) and 17a-ethynyl estradiol (EE2) have been demonstrated to exert adverse effects in exposed organisms. E2 and EE2 have been proposed for inclusion in the Water Framework Directive (WFD) list of priority pollutants; however, the detection and accurate quantification of these compounds provide significant challenges, due to the low detection limits required.

METHODS: A sensitive method combining ultrasonication, solid-phase extraction (SPE) and liquid chromatography/tandem mass spectrometry, with electrospray ionisation in negative mode (LC/ESI-MS/MS), capable of determining E1, E2 and EE2 at concentrations between 0.07 and $60 \mathrm{ng} / \mathrm{L}$ for seawater and between 0.4 and $200 \mathrm{ng} / \mathrm{g}$ wet weight in Mytilus spp. is reported.

Recoveries at the limit of quantification (LOQ) ranged from 95 to $102 \%$ and 88 to $100 \%$ for water and tissue, respectively. Salinity (12 to 35\%) and typical marine particulate matter loadings (between 10 and $100 \mathrm{mg} / \mathrm{L}$ ) were not found to affect analyte recoveries. RESULTS: The first detection of E1 by LC/MS/MS in Irish marine waters (Dublin Bay, at 0.76 ng/L) is reported. Steroids were not detected in Galway Bay, or in any mussel samples from Dublin, Galway and Clare. The level of E2 detected in the dissolved water phase was below the proposed WFD Environmental Quality Standard (EQS) in other surface waters. CONCLUSIONS: The proposed method is suitable for the detection of E1, E2 and EE2 at biologically relevant concentrations and, due to the specificity offered, is not subject to potential interferences from endogenous E1 and E2 which often complicate the interpretation of estrogenic biomarker assays.

In recent decades, scientific and legislative communities have become increasingly aware of the presence and effects of endocrine-disrupting compounds (EDCs) in the environment. ${ }^{[1]}$ These compounds, which may be natural or synthetic in nature, interfere with the hormonal system of exposed organ-isms, by mimicking, antagonising, altering the pattern or synthesis of endogenous hormones, or modifying hormone receptor levels. ${ }^{[2]}$ They may reach the environment via a number of sources, including municipal and industrial wastewater effluent, agricultural and terrestrial run off and accidental release. ${ }^{[3-5]}$ At present, the EDCs receiving most attention are those that, despite their diverse chemical structures, mimic estrogens. ${ }^{[6]}$ Of the myriad compounds which have been shown to exert estrogenic effects, the natural and synthetic ster-oid estrogens have among the highest potencies. These include estrone (E1) and 17b-estradiol (E2), the naturally occurring estrogens, and 17a-ethynyl estradiol (EE2), the synthetic estro-gen used in the contraceptive pill..$^{[7,8]}$

\footnotetext{
* Correspondence to: J. M. Ronan, School of Natural Sciences, University of Dublin, Trinity College, Dublin 2, Ireland. Email: jenny.ronan@marine.ie
}

A number of international studies have shown the biological effects of steroid estrogens, including decreased fecundity, increased levels of vitellogenin (VTG) in females, vitellogenesis in male organisms and the development of ovotestis and other stages of intersex in male organisms. ${ }^{[9-14]}$ Estrogens may be excreted and released into the environment as inactive conjugates (mainly glucuronides and sulphates); however, deconjugation by bacterial enzymes in wastewater treatment plants (WWTPs) reactivates these conjugates into biologically active parent compounds ${ }^{[15,16]}$ and they have been detected in surface waters and in wastewater influent and effluent. ${ }^{[17-19]}$ EE2 is resistant to degradation in order to be effective as an oral contraceptive and it is degraded at a lower rate than the natural estrogens. ${ }^{[20,21]}$ Most research to date has focused on freshwater environments. Far less is known on the presence and effects of these compounds in marine and estuarine environments. ${ }^{[2,23]}$ Thus, there is a substantial need for research in this area.

The increasing body of scientific data which has demonstrated the negative effects of EDCs in the environment has led to the development of monitoring programmes and the passage of legislation which aim to reduce the amount of EDCs present in the environment. In Europe, the Water Framework Directive (WFD, 2000/60/ EC) has defined a list of priority 
pollutants which are deemed to have detrimental effects in the environment, with a requirement for substantial monitoring of these pollutants in transitional and coastal waters to achieve "good ecological and chemical status" by 2015. A number of these compounds have endocrine-disrupting properties, and environmental quality standards (EQSs) defining maxi- mum allowable concentrations (MACs) and annual average (AA) concentrations permitted in coastal and transitional waters have been defined. E2 and EE2 have recently been proposed for inclusion on this listing with provisional AA EQS of 0.08 and $0.007 \mathrm{ng} / \mathrm{L}$, respectively, defined for other surface waters. Should legislation to include E2 and EE2 on the WFD priority pollutant list be adopted, sensitive and selective methods will be essential in order to comply with WFD monitoring requirements.

Determining the levels and potential for effects of these compounds in marine environments can prove challenging, due to the low detection limits required, which are often exacerbated by high dilution factors. The analytical difficulties associated with the determination of low estrogen concentrations have also proved challenging. ${ }^{[18]}$ The main methods used for the analysis of estrogens in environmental matrices are liquid and gas chromatography (LC and GC) coupled with mass spectrometry (MS) or tandem mass spectrometry (MS/MS). ${ }^{[24]}$ The use of GC necessitates a derivatisation step, which is time consuming and labour intensive. ${ }^{[18]}$ Liquid chromatography/tandem mass spectrometry (LC/MS/MS) has emerged as the leading method of analysis for the steroid estrogens due to its high sensitivity and specificity and rapid sample throughput, ${ }^{[25]}$ with ionisation in negative electro- spray mode (ESI) the most commonly used. ${ }^{[24]}$

Mytilus spp. are widely distributed sessile filter-feeding bivalves which play an important role in coastal ecology. ${ }^{[26]}$ They are abundant, have a primary benthic life stage, filter large amounts of water, bioaccumulate many compounds and have a relatively stable population which enables repeated sampling. They are easily transplanted and maintained, making them suitable for use in monitoring studies when indigenous populations may not be present, or for investigations of point sources of contaminants. They are also a significant contributor to the human food supply. They are widely used to assess the status and trends of chemical contamination in estuarine and coastal environments within the monitoring programmes of Oslo Paris Commission (OSPAR), the WFD and will continue to have a role in ongoing monitoring activities in support of Marine Strategy Framework Directive (MSFD, 2008/56/EC) objectives.

Vertebrate-like steroids have been identified in mussels, ${ }^{[27]}$ although their exact modes of action, endogenous origin and physiological role remain to be elucidated. ${ }^{[28]}$ Endogenous hormones may complicate the interpretation of bioassays which measure estrogenic responses in Mytilus spp. Seasonal E2 levels, measured using an enzyme-linked immunosorbent assay (ELISA), have been reported in Mytilus galloprovinciallis, ranging from 1.71 to $5.42 \mathrm{ng} / \mathrm{g}$ dry weight (dw). ${ }^{[2]}$ Two methods have been developed for the detection of steroids in Mytilus spp. using MS techniques, ${ }^{[30,31]}$ however, both methods were unsuccessful in detecting natural levels of endogenous steroids.

This paper details the development, validation and application of a quality-assured sensitive LC/MS/MS method for the detection of steroid estrogens at sub-ng/L concentrations in seawater and at low ng/g concentrations in Mytilus spp. The influences of salinity and particulate matter on analytical results are investigated. The application of the method for pro- posed WFD screening/surveillance monitoring of E2 in coastal and transitional waters is evaluated. The method is capable of the accurate detection of endogenous steroids in Mytilus spp. at trace levels. This confers the potential to better define seasonal variations in natural hormone levels, which can be complicating factors in interpreting the results of estrogenic bioassays and biomarker studies, and to detect anthropogenic versus natural increases in steroid levels.

\section{EXPERIMENTAL}

\section{Chemicals}

Pestiscan grade solvents acetonitrile, methanol, methyl tert- butyl ether, ethyl acetate, and n-hexane $99 \%$ were supplied by Fisher Scientific (Dublin, Ireland). Triethylamine, formic and acetic acids, formalin, E1, E2, b-estradiol-d 2 (E2D2), EE2 and warfarin (WF) standards were obtained from Sigma-Aldrich Ireland Ltd. (Arklow, Ireland). Purified deionised (DI) water was provided using a Barnstead water purification system (Thermo Scientific, Loughborough, UK). Stock standards solutions of E1, E2 and EE2 were prepared in $\mathrm{CH}_{3} \mathrm{OH}$ at $1 \mathrm{mg} / \mathrm{mL}$, with the exception of E2D2 which was prepared at $200 \mathrm{ng} / \mathrm{mL}$.

\section{Standard preparation and batch quality control}

Working solutions of each analyte, mixtures and spiking solutions were prepared at different concentrations by appropriate dilution of the stock solution in $\mathrm{CH}_{3} \mathrm{OH}$. Final calibration standards for water analysis were prepared in 20:80 $\mathrm{CH}_{3} \mathrm{OH} / \mathrm{H}_{2} \mathrm{O}$ while those for tissue were prepared in

$\mathrm{CH}_{3} \mathrm{OH}$. All solutions were stored at $<4{ }^{\circ} \mathrm{C}$ in the dark and used within 1 month. A standard curve was generated from

eight standards of increasing concentration injected prior to each batch of samples analysed. For water, calibration standards in 20:80 $\mathrm{CH}_{3} \mathrm{OH} / \mathrm{H}_{2} \mathrm{O}$ were injected prior to samples. Calibration of tissue samples was conducted using matrix-matched standards in order to account for biological matrix ion suppression in the mass spectrometer. Final calibration standards were prepared in $\mathrm{CH}_{3} \mathrm{OH}$ at a range of concentrations. These calibration standards were spiked onto individual blank tissue samples and taken through the full extraction and analysis procedure. The standard curve generated from these matrix-matched standards was used to quantify any analytes present in samples. For each analysis of both water and biota a solvent blank, a procedural blank and two fortified samples along with repeat injections of a working standard were analysed as quality controls. As no certified reference materials were available, recoveries of additions of known amounts of the target analytes to artificial seawater and fortified blank tissue were used to assess batch and method performance. The method performance para- meters are presented in Table 1.

\section{Site selection and sampling}

Water and mussel samples were collected from three locations on the Irish coast in June 2010. Site 1, the North Bank Light- house (NBL), is situated in the estuary of the River Liffey, 
Table 1. LCMS/MS method performance parameters

\begin{tabular}{|c|c|c|c|}
\hline & Estrone & 17b-Estradiol & 17a-Ethynyl estradiol \\
\hline \multicolumn{4}{|l|}{ Tissue parameters $(n g / g w w)$} \\
\hline LOD & 0.4 & 0.9 & 0.3 \\
\hline LOQ & 0.7 & 1.7 & 0.6 \\
\hline Linear range & $0.4-200$ & $0.9-201$ & $0.3-202$ \\
\hline $\mathrm{R}^{2}$ standard curve & 0.999 & 0.996 & 0.999 \\
\hline Recovery $(\%)$ at LOQ & 88 & 100 & 93.2 \\
\hline Precision (RSD\%) at LOQ & 8.7 & 8.2 & 3.2 \\
\hline \multicolumn{4}{|l|}{ Water parameters $(n g / L)$} \\
\hline LOD & 0.07 & 0.07 & 0.11 \\
\hline LOQ & 0.12 & 0.12 & 0.15 \\
\hline Linear range & $0.07-60$ & $0.07-60$ & $0.11-60$ \\
\hline $\mathrm{R}^{2}$ standard curve water & 0.999 & 0.999 & 0.999 \\
\hline Recovery $(\%)$ at LOQ & 97.2 & 97 & 102 \\
\hline Precision (RSD\%) at LOQ & 9 & 3.1 & 4.3 \\
\hline
\end{tabular}

which flows into Dublin Bay, a shallow bay on the east coast of Ireland (N 53 20'41'; W 06 ${ }^{0} 11^{\prime} 35^{\prime}$ '). Effluent from the Ringsend tertiary (UV sterilisation) wastewater treatment plant (WWTP), which serves a population equivalent (PE) of 1,640,000 from Dublin City and surrounds, enters the bay in this estuary. Water and mussel samples were collected at NBL, which is situated $700 \mathrm{~m}$ downstream of the effluent discharge. Site 2, Mutton Island (MI), is situated in Galway Bay, a shallow bay situated on the west coast of Ireland. Samples were collected above the diffuser pipe of Mutton Island WWTP, which serves a PE of 91,600 from Galway City and surrounds, providing secondary treatment (activated sludge) to effluents (N 53015'13', W 09003'17''). Site 3, Redbank hatchery, Aughinish Co. Clare (N 53009'27.28; W $09^{\circ} 04^{\prime} 03.84$ ), is situated on the west coast of Ireland and has been defined as 'Class A' for the purposes of EC Regulation 854/2004. This means that there is no indication of faecal contamination and wastewater, a major source of EDCs, in the area (DEHLG, 2007). Development and validation of methods prior to the analysis of test samples were completed on mussels (4 to $6 \mathrm{~cm}$ ) from this location. Five $\mathrm{L}$ surface water samples were collected in amber glass bottles, which had previously been washed with $\mathrm{CH}_{3} \mathrm{OH}$. The potential effects of UV degradation were minimised during this study by ensuring that all samples and extraction steps were protected from light. The water samples were filtered with $0.45-\mathrm{mm}$ glass fibre filters (Whatman GF-F, General Electric, Piscataway, NJ, USA) and $50 \mathrm{~mL}$ of formalin $(1 \% \mathrm{v} / \mathrm{v})$ was added per sample to prevent bacterial growth, and the samples were stored in the dark at $4{ }^{0} \mathrm{C}$ prior to LC/MS/MS analysis. Thirty mussels measuring 4-6 cm were collected per site and transported to the lab in cold conditions. The mussels were dissected, the whole soft tissue weight recorded and the shell length measured to the nearest $\pm 0.1 \mathrm{~mm}$ using callipers. The tissue was homogenised using a Waring blender (Waring Commercial, New Hartford, CT, USA), freeze-dried and frozen at $-30{ }^{0} \mathrm{C}$ prior to analysis. It should be noted that the Irish coastal zone contains a mixture of pure, hybrid and introgressed individuals, ${ }^{[32]}$ and, since there is no single morphological characteristic that can be reliably used to separate this mixed population, classification of the exact Mytilus species used in this study was not possible.
Extraction of mussel tissue and water sample preparation

The extraction method was modified from a number of existing extraction methods for water, sediment and biota, ${ }^{[33-38]}$ and further developed and validated to be specific to the extraction of complex mussel tissues. The tissue samples were extracted as follows: $10 \mathrm{~mL}$ of $\mathrm{CH}_{3} \mathrm{OH}$ was added to a $50 \mathrm{~mL}$ centrifuge tube containing $0.5 \mathrm{~g}$ of freeze-dried tissue and extracted by ultrasonication for $1 \mathrm{~min}$. The samples were centrifuged at $2800 \mathrm{~g}$ for $5 \mathrm{~min}$ and the supernatant collected. The probe was rinsed with $10 \mathrm{~mL} \mathrm{CH} \mathrm{CH}_{3} \mathrm{OH}$ for 30 s. Then $10 \mathrm{~mL}$ of $\mathrm{CH}_{3} \mathrm{OH}$ was added to the pellet, which was re- extracted for $1 \mathrm{~min}$ by ultrasonication, and centrifuged as above. Lipid removal was conducted after extraction by centrifugation of the extract at $2800 \mathrm{~g}$ for $5 \mathrm{~min}$ with $20 \mathrm{~mL}$ of $\mathrm{n}$-hexane $(99 \%)$. The $\mathrm{CH}_{3} \mathrm{OH}$ fraction was reduced to dryness under nitrogen at $35{ }^{\circ} \mathrm{C}$ and resuspended with $9 \mathrm{~mL}$ deionised water. Prior to solid-phase extraction (SPE), 5$\mathrm{L}$ water samples were filtered with $0.45-\mathrm{mm}$ glass fibre filters (Whatman GF-F).

\section{Clean up by SPE}

Sample clean-up was conducted using Oasis hydrophiliclipophilic-balanced (HLB) SPE cartridges (3 mL, $60 \mathrm{mg}$; Waters, Milford, MA, USA). For water samples, Bakerbond $\mathrm{SPE}^{\mathrm{TM}} 75-$ $\mathrm{mL}$ reservoirs (J.T. Baker, Avantor Performance Materials, Centre Valley, PA, USA) were attached to the SPE cartridges to enable application of the sample. The cartridges were rinsed and conditioned with $3 \mathrm{~mL}$ pestiscan grade $\mathrm{CH}_{3} \mathrm{OH}$ and deionised water, prior to addition of the sample extract. The cartridges were then rinsed with $3 \mathrm{~mL} 5 \% \mathrm{CH}_{3} \mathrm{OH}$ in deionised $\mathrm{H}_{2} \mathrm{O}$, and the samples were eluted in $2 \mathrm{~mL} \mathrm{CH}_{3} \mathrm{OH}$ under a gentle vacuum. The sample was then reduced to dryness under nitrogen at $35{ }^{0} \mathrm{C}$ and resuspended in $130 \mathrm{~mL}$ of $1: 4 \mathrm{CH}_{3} \mathrm{OH} /$ water. Then $10 \mathrm{ng}$ of external standard warfarin (Sigma Aldrich, St. Louis, MO, USA) was added, and $20 \mathrm{~mL}$ of this solution was injected into the HPLC system.

Investigation of potential impacts of cofactors on EDC analysis

As estuarine and marine waters will differ in their salinity profile, the potential for saline-induced effects on analysis was examined. Saline water was prepared at a range of 
salinities (12, 24 and 35\%) using deionised water, sodium chloride and sodium hydrogen carbonate. This water was spiked with E1, E2 and EE2 at $80 \pm 2 \mathrm{ng} / \mathrm{L}$. The proposed EQS values are set for total water, which includes the particulate phase. The water samples were filtered $(<0.45 \mathrm{~mm})$ prior to analysis to remove larger debris and some particulate matter which might block the SPE cartridges. To assess the potential impact of filtration/removal of particulate matter (PM) loadings on analyte recovery, PM (sediment particle size $<63 \mathrm{~mm}$ ) was added at $10 \mathrm{mg} / \mathrm{L}$ and $100 \mathrm{mg} / \mathrm{L}$ to both the spiked and the blank jars containing deionised water. Each experimental set of conditions was repeated in triplicate. The particulate matter used was dried marine sediment with a total organic carbon (TOC) content of $3.8 \%$. Jars containing both spiked and unspiked water without PM addition were also analysed. The jars were shaken overnight on an orbital shaker (Stuart Ltd., Bibby Scientific Ltd., Stone, UK), filtered, extracted and analysed by LC/MS/MS. PM retained on each filter paper was also extracted and analysed. The results for all the co- factor testing are detailed below.

\section{Liquid chromatography}

The HPLC system consisted of an Agilent 1200 Series game pad, an Agilent 1200 binary pump, an Agilent 1200 highperformance autosampler and an Agilent 1200 thermostatted column compartment (Agilent Technologies Deutschland $\mathrm{GmbH}$, Böblingen, Germany). For LC separation a Kinetex C18 column (4.6 x $50 \mathrm{~mm}, 2.1 \mathrm{~mm}$ i.d., $2.5 \mathrm{~mm}$ particle size) and a Luna C8 column (5 mm, $100 \AA$ А $50 \times 2.0 \mathrm{~mm})$
(Phenomenex, Macclesfield, UK) were tested over a range of column oven temperatures $\left(25\right.$ to $\left.40{ }^{\circ} \mathrm{C}\right)$. The sharpest peaks and best separation were achieved with the Kinetex C18 column (Fig. 1) with an oven temperature of $30{ }^{\circ} \mathrm{C}$. For the LC/MS/MS experiments, a model 3200 Q-TRAP quadrupole ion trap tandem mass spectrometer system (Applied Biosystems, Foster City, CA, USA) was used, equipped with an electrospray ionization (ESI) ion source. The mobile phases were $0.025 \%$ triethylamine (TEA) in deionised water (A) and $0.025 \%$ TEA in 5:95 water/acetonitrile (B) flowing at $300 \mathrm{~mL} / \mathrm{min}$ with a gradient as follows: 0 to $2 \mathrm{~min}$ ( 5 to $31.5 \% \mathrm{~B}$ ), 2 to $7 \mathrm{~min}$ ( 31.5 to $34 \%$ B), 7 to $9 \min (100 \% \mathrm{~B})$ and 9 to $12 \mathrm{~min}(5 \% \mathrm{~B})$. Full separation was not necessary for the selective MS/MS detection, ${ }^{[39]}$ but it was achieved for most of the compounds analysed in this method. Chromatograms of a standard and a formalin-treated blank sample are presented in Figs. 1(a) and 1(b), respectively.

\section{Electrospray tandem mass spectrometry}

Due to the complexity of the matrix, a tandem mass spectrometry (MS/MS) method was selected for the analyis. Optimisation of the ESI ion source and the MS/MS settings was performed by the automatic optimisation function of the LC/MS/MS software (Analyst 1.4, Applied Biosystems), and fine tuned manually using infusion with a syringe pump and flow injection analysis of standard solutions. The ESI source (Turbo-Ionspray, Applied Biosystems) was operated in negative ion mode, and optimised over a range of voltages $(-2000$ to $-4500 \mathrm{~V})$ and source temperatures $(50$ to $650{ }^{\circ} \mathrm{C}$ ) with final optimised conditions of $550{ }^{\circ} \mathrm{C}$ and $-4400 \mathrm{~V}$. Nitrogen was

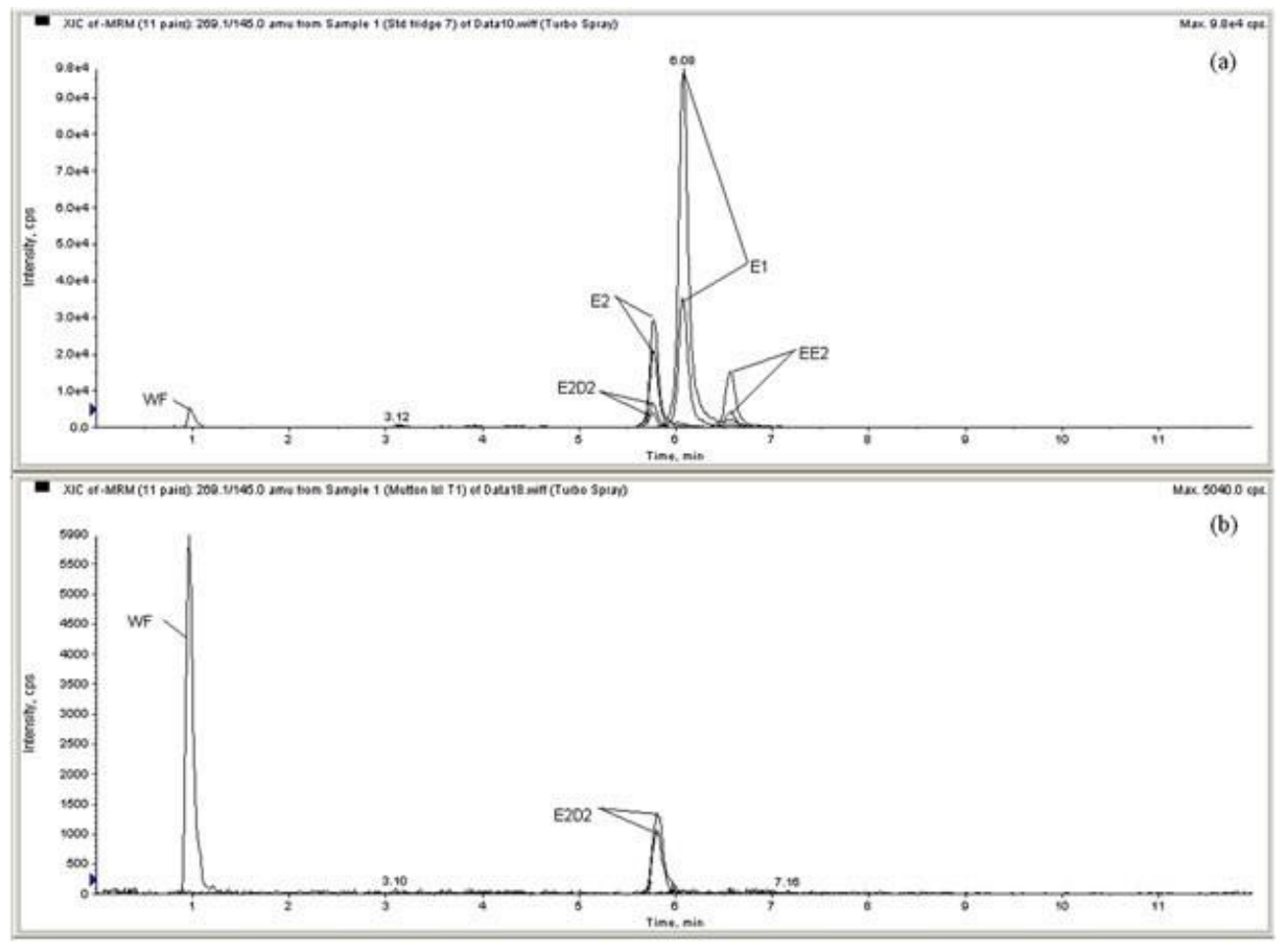

Figure 1. Compound separation. Chromatograms of (a) standard and (b) formalin-treated blank sample. E1 = estrone, E2 = 17b-estradiol, EE2 = 17a-ethynyl estradiol, E2D2 = 17b-estradiol- $d_{2}, \mathrm{WF}=$ warfarin. 
used as the nebuliser, drying, curtain and collision gas. Gas one (GS1nebuliser gas) was adjusted to a pressure of 35 psi and gas two (GS2-drying gas) to a pressure of 50 psi after optimisation over a range of pressures (10 to $60 \mathrm{psi}$ ). The curtain gas pressure was optimised to $44 \mathrm{psi}$. The precursor-product ion transitions and optimised collision energy (CE), entrance potential (EP), declustering potential (DP), collision cell entrance potential (CEP) and collision cell exit potential (CXP) for each analyte are presented in Table 2. For quantification

the multiple reaction monitoring (MRM) mode was selected. The dwell time for each precursor-product ion was $75 \mathrm{~ms}$. Quantification was performed using matrix-matched standards for mussel tissue, and aqueous standards for water samples. Conversion factors were calculated based on the tis- sue wet weight divided by the dry weight for each sample. Method detection limits were determined by calculating at a $99 \%$ confidence level the standard deviation of the mean response of a minimum of 10 analyses of low-level fortified blank samples and by generation of the relevant response factor plots. The method performance parameters are presented in Table 1.

\section{RESULTS AND DISCUSSION}

The main aim of this study was to develop a rapid sensitive method for the determination of trace E1, E2 and EE2 levels in seawater and biota, using SPE for water, and ultrasonication and SPE for biota samples, followed by LC/ESI-MS/ MS. Details on optimisation for the purposes of marine matrices are presented below.

\section{High-speed separation and ESI-MS/MS}

The mobile phases selected were deionised water (A) and 5:95 water/acetonitrile (B). TEA was selected as the mobile phase buffer. The addition of 0.001 to $0.01 \%$ TEA was tested, with $0.025 \%$ TEA in each mobile phase producing the most intense signal responses for the steroids. Formic acid and ammonium formate were also tested as buffers, but failed to produce sufficiently intense signals. $\mathrm{CH}_{3} \mathrm{OH}$ was tested in place of $\mathrm{CH}_{3} \mathrm{CN}$ in mobile phase $\mathrm{B}$, but resulted in poor separation of the target analytes.
Tissue method development and quantification

A number of different tissue extraction methodologies were examined prior to analysis of the analytical samples. The optimised extraction and SPE conditions are presented in the Experimental section. Ion suppression, and less frequently enhancement, due to matrix interference from co-extracted matrix components is a common problem in LC/ESI-MS/MS analysis when analysing biological matrices. . ${ }^{[39] \quad \text { Warfarin }}$ (WF) was selected as the external standard, to account for ion suppression during analysis. Blank tissue was fortified gravimetrically with analytes over a concentration range of 0.4 to $200 \mathrm{ng} / \mathrm{g}$ ww (wet weight) and taken through the extraction procedure as detailed above. The recoveries of target analytes using this method were 88 to $100 \%$.

\section{Water method development and SPE}

The selection of an appropriate solid sorbent to the target analyte as well as the use of solvents for washing and elution $^{[40]}$ is fundamental to EDC analysis. Following rigorous testing of a number of commercially available sorbent materials during method development (unpublished $\mathrm{r}$ esults), Oasis HLB cartridges were employed using a $2 \mathrm{~mL} \mathrm{CH}_{3} \mathrm{OH}$ elution solvent. The final SPE method selected was a modification of a number of reported methods ${ }^{[33,41-43]}$ The use of a deuterated internal standard (17b-estradiol- $\left.\mathrm{d}_{2}, \mathrm{E} 2 \mathrm{D} 2\right)$ and an external standard (warfarin, WF) was found to dramatically improve data precision to assess recovery and reproducibility. E2D2 was selected as the internal standard, taken through the full extraction procedure, used to confirm retention times and to quantify any losses throughout the extraction and preconcentration steps. WF was used as the external standard added directly before LC/MS/MS analysis. Calibration curves were obtained using fortified tissue samples spiked at different concentrations of E1, E2 and EE2 (for linear range, see Table 1). Using WF to quantify the sample concentrations resulted in better data precision and more reproducible results than those calculated using E2D2, with recoveries of 88 to $102 \%$, relative standard deviation (RSD) 3.2 to $9 \%$ calculated using WF, compared with 59 to $70 \%$ recovery and RSD of 35 to $42 \%$ using E2D2. WF was then selected as external standard for quantification, with E2D2 used to confirm retention times and to quantify any losses throughout the extraction.

\begin{tabular}{|c|c|c|c|c|c|c|c|}
\hline Compound & $\begin{array}{c}\text { Precursor ion } \\
(\mathrm{m} / \mathrm{z})\end{array}$ & $\begin{array}{l}\text { Product ions } \\
(\mathrm{m} / \mathrm{z})\end{array}$ & $\begin{array}{l}\text { DP } \\
(V)\end{array}$ & $\begin{array}{l}\text { EP } \\
(V)\end{array}$ & $\begin{array}{l}\text { CEP } \\
\text { (V) }\end{array}$ & $\begin{array}{l}\mathrm{CE} \\
(\mathrm{eV})\end{array}$ & $\begin{array}{l}\text { CXP } \\
\text { (V) }\end{array}$ \\
\hline \multirow[t]{2}{*}{ Estrone } & \multirow[t]{2}{*}{269} & 145 & -90 & -8 & -16 & -16 & 2 \\
\hline & & 142 & -90 & -8 & -16 & -66 & -2 \\
\hline \multirow[t]{2}{*}{ 17b-Estradiol } & \multirow[t]{2}{*}{271} & 145 & -90 & -8.5 & -14 & -50 & 2 \\
\hline & & 183 & -90 & -8.5 & -14 & -52 & -4 \\
\hline \multirow{2}{*}{$\begin{array}{l}\text { 17a-Ethynyl } \\
\text { estradiol }\end{array}$} & \multirow[t]{2}{*}{295} & 145 & -82 & -10 & -13 & -54 & -4.6 \\
\hline & & 199 & -48 & -10 & -17 & -54 & -7.8 \\
\hline
\end{tabular}


The recovery range and repeatability of extraction as presented were deemed fit for purpose and further analytical recovery was not required.

\section{Assessment of the influence of cofactors on EDC analysis}

The impact of sample volume was examined by the extraction of spiked water volumes ranging from $100 \mathrm{~mL}$ to $5 \mathrm{~L}$. The recoveries at each volume $(100,250,500,1000$ and $5000 \mathrm{~mL})$ were $65-127 \%$ for E1, $72-132 \%$ for E2, and $69-129 \%$ for EE2. At low concentrations and low sample volumes (e.g. $0.5 \mathrm{ng}$ in 100 $\mathrm{mL}$, equivalent to $5 \mathrm{ng} / \mathrm{L}$ ) the recoveries were highly variable. A 5-L sample size was selected as optimal for analysis purposes. The recoveries of spiked EDCs ranged from 88 to $102 \%$, with RSDs of 3.2 to $9 \%$. The recovery differences between different salinity regimes were compared using a one-way analysis of variance (ANOVA) with assumption tests of normality and equal variance performed prior to ANOVA. There was no statistically significant difference $(P=0.14,0.77$ and 0.13 for E1, E2 and EE2, respectively) between salinities; thus, salinity alone was deemed not to influence the dissolved concentrations of EDCs. The concentration of suspended particulate matter in seawater is typically $<15 \mathrm{mg} / \mathrm{L},{ }^{[44,45]}$ with increases up to $70 \mathrm{mg} / \mathrm{L}$ occurring in certain areas, such as river plumes. ${ }^{[4,46]}$ Sorption of steroid estrogens under estuarine conditions is relatively slow, with sorption equilibrium reached after 70 to $170 \mathrm{~h}$ for E1 and E2, respectively. ${ }^{[47]}$ Analysis of the extracted filter papers gave concentrations that were < LOD (range 0.4 to $1.7 \mathrm{ng} / \mathrm{g} \mathrm{dw}$ ) for all compounds. The recoveries of dissolved E1, E2 and EE2 in the filtered extracts were 51,84 and $51 \%$, respectively. The fact that levels were not detected in the particulate phase but with reduced recovery in the water phase suggests that all three compounds primarily remained in the water phase, but might be subject to differing degrees of degradation during the overnight shaking process at room temperature. Similar reductions in concentration after $24 \mathrm{~h}$ in spiked seawater have been noted for E2 and EE2 by Ciocan et al. ${ }^{[48]}$ and for E1, E2 and EE2 by Van den Belt et al. ${ }^{[49]}$ Lopez de Alda and Barceló ${ }^{[50]}$ also found that filtration did not lead to significant losses of estrogens from water samples. The steroid estrogens typically have rapid degradation rates, with half-lives reported ranging from hours to days. ${ }^{[51-53]}$ In a laboratory study on the fate and behaviour of estrogens in river waters, Jürgens et al ${ }^{[17]}$ found that the steroid estrogens undergo aerobic degradation and attributed this to bacterial degradation, as no degradation was observed in sterile controls. Labadie and Budzinski ${ }^{[35]}$ and Jürgens et al. ${ }^{[54]}$ found that bacterial degradation resulted in half-lives of E1 of 0.2 to 7.2 days. It is possible that degradation occurred due to the presence of bacteria in the sediment. While of limited concern for the data reported herein, it is important to note that deconjugation by bacterial enzymes in WWTPs, or in the aquatic environment, reactivates these conjugates to the biologically active parent compounds; ${ }^{[15,16]}$ thus, they can still be present in the environment, even after treatment in a WWTP. It should be noted that secondary treatment processes, such as activated sludge, have been shown to remove up to $90 \%$ of E1, E2 and EE2 from wastewater during treatment ${ }^{[55,56]}$ while UV sterilisation has been demonstrated to remove between 70 and $100 \%$ of E1, E2 and EE2 from wastewater during treatment. ${ }^{[56]}$

\section{Analysis of steroid estrogens in water and biota samples}

Estrone was detected at NBL at $0.76 \mathrm{ng} / \mathrm{L}$ (Table 3), while E2 and EE2 were not detected in seawater (LOD 0.08 and $0.14 \mathrm{ng} / \mathrm{L}$, respectively). These are the first measurements of E1 concentrations in receiving waters in Dublin Bay by LC/MS/MS. The estrogenicity of effluent and receiving waters from the Ringsend WWTP has previously been deter- mined using the yeast estrogen screen, and this was conducted prior to the addition of tertiary UV treatment at the plant in a study by Tarrant et $a l .{ }^{[52]}$ The estrogenicity, expressed as estradiol equivalents, was $16 \mathrm{ng} / \mathrm{L}$ in effluent but was not detected in receiving waters. The samples in this study and in the study of Tarrant et al. ${ }^{[52]}$ were collected using spot samples, which only provide a snapshot of a single moment in what is generally a dynamic environment. A study by Williams et al. ${ }^{[57]}$ showed that daily grab samples of waters taken from a river had a wide variance in daily $\mathrm{E} 1$ concentrations, ranging from 0.32 to 2.5 ng/L. Potential sources of E1 detected in this study included Ringsend WWTP effluent, and/or other effluent or agricultural run-off entering upstream in the River Liffey catchment.

Table 3. Results

\begin{tabular}{|c|c|c|c|}
\hline & NBL, Dublin Bay & Mutton Island, Galway Bay & Aughinish Bay, Co. Clare \\
\hline \multicolumn{4}{|c|}{ Water $(n g / L)$} \\
\hline E1 & 0.76 & nd $(0.07)$ & $\mathrm{n} / \mathrm{a}$ \\
\hline E2 & nd (0.07) & nd $(0.07)$ & $\mathrm{n} / \mathrm{a}$ \\
\hline EE2 & nd $(0.11)$ & nd $(0.11)$ & $\mathrm{n} / \mathrm{a}$ \\
\hline $\mathrm{n}=$ & 1 & 1 & $\mathrm{n} / \mathrm{a}$ \\
\hline \multicolumn{4}{|c|}{ Mussels ( $n g / g$ wet weight) } \\
\hline E1 & nd $(0.4)$ & nd $(0.4)$ & nd $(0.4)$ \\
\hline E2 & nd $(0.9)$ & nd $(0.9)$ & nd $(0.9)$ \\
\hline EE2 & nd $(0.3)$ & nd $(0.3)$ & nd $(0.3)$ \\
\hline $\mathrm{n}=$ & 1 & 1 & 4 \\
\hline
\end{tabular}


The concentration of E1 detected is consistent with values reported in surveys of receiving waters and coastal waters, with estrogens generally reported in the range of $<1$ to $10 \mathrm{ng} / \mathrm{L}$. ${ }^{[57,58]}$ Steroid estrogens have been detected in WWTP effluent in concentrations up to 82, 3.5 and $1.7 \mathrm{ng} / \mathrm{L}$ for E1, E2 and EE2, respectively. Atkinson et al. ${ }^{[22]}$ studied E1 distribution in coastal and oceanic sites using radioimmunoassay (RIA), and found the highest concentrations of E1 near sources of wastewater. E1 was not detected (LOD $4 \mathrm{ng} / \mathrm{L}$ ) in the open ocean but was detected up to almost $200 \mathrm{ng} / \mathrm{L}$ in the coastal areas of Key West, Florida, USA, and Rehoboth Bay, Delaware, USA. Values reported for the three selected Irish coastal sites in this study are low relative to other similar studies in industrialised coastal and estuarine areas, despite Dublin Bay being one of the more industrialised locations in Ireland.

E1, E2 and EE2 were not detected in any mussel sample, despite the proximity of mussels in Dublin and Galway to WWTP effluent inputs. Furthermore, E1 and E2 were not detected in a seasonal study of EDC levels in mussels from the Redbank hatchery in Aughinish Bay ( $n=4$ samples, Table 3). The mussels from this site have been used in a number of transplantation and in vivo studies ${ }^{[59,60]}$ and characterising potential temporal variation is an essential prerequisite for the evaluation of EDC levels and potential impacts on test species, and in monitoring studies.

A variety of concentrations of endogenous steroids have been reported for Mytilus spp. A review by Janer and Porte ${ }^{[61]}$ reported that E2 levels in molluscs are spread over 4 orders of magnitude, depending on the species and method used for detection. E2 has been reported to be present at up to $5.42 \mathrm{ng} / \mathrm{g}$ dry weight (dw) in M. galloprovinicallis using ELISA, ${ }^{[29]}$ and up to $2.5 \mathrm{ng} / \mathrm{g}$ and $0.2 \mathrm{ng} / \mathrm{g}$ wet weight (ww) in M. edulis gonad tissue and peripheral tissue, respectively, using RIA. ${ }^{[62]}$ Detection of steroids at and below these concentrations using MS techniques has proved challenging, despite the development of methods with very sensitive detection limits. Steroids were not detected in Mytilus spp. using GC/MS, despite the technique having detection limits of 0.1 to $0.2 \mathrm{ng} / \mathrm{g}$ ww. ${ }^{[30]}$ Pojana et al. ${ }^{[31]}$ used LC/MS/MS to analyse E1, E2 and EE2 in mussels taken from the highly urbanised Venetian coastal lagoon. EE2 was detected at 7.2 to $38 \mathrm{ng} / \mathrm{g} \mathrm{dw}$, but E1 and E2 were not detected, with LODs of $1.5 \mathrm{ng} / \mathrm{g} \mathrm{dw}$ ( $\sim 0.3 \mathrm{ng} / \mathrm{g}$ ww assuming $20 \%$ dry matter). The LODs attained in this study (0.4 to $1.7 \mathrm{ng} / \mathrm{g}$ ww) are similar to those reported by Pojana et al. ${ }^{[31]}$ and Dévier et al. ${ }^{[30]}$

Immunoassay techniques, while generally rapid and inexpensive, are less specific than MS. The specificity of RIA may be limited by cross-reactivity or subjected to interferences from co-extracted matrix components. ${ }^{[63]} \mathrm{Zhu}$ et $a l .{ }^{[14]}$ reported E2 levels of $165 \pm 54 \mathrm{ng} / \mathrm{g}$ ww in M. edulis gonad tissue, using quadrupole-time-of-flight mass spectrometry (QTOF-MS), and $854 \mathrm{ng} / \mathrm{g}$ using RIA. Further investigation using Q-TOF-MS revealed two E2 immunoreactive materials present in the sample, one corresponding to authentic E2, and the other with a four times higher E2 reactivity, which the authors concluded was an E2 isoform. Endogenous E2 was detected in the gastropod snail Potamopyrgus antipodarium by Gust et al. ${ }^{[63]}$ using RIA; how- ever, the authors could not detect E2 using LC/ESI-MS/MS. They concluded that the levels detected by RIA should be used with caution due to the possible presence of interfering substances and cross-reactivity. The discrepancy between E2 results by MS and RIA might explain why some sensitive MS techniques are unable to detect E2 at the concentrations reported by RIA despite the techniques having similar LODs. The specificity of MS detection as reported herein allows the detection of 'authentic' E2 and not the E2 isoform detected using RIA. MS techniques are a powerful tool for the accurate elucidation of the concentration and profiles of endogenous steroids in Mytilus spp. Natural and synthetic steroid estrogens have been shown to be biologically active at low concentrations; thus, successful analysis requires low detection limits, and highly sensitive and selective analysis. Seasonal fluctuations in endogenous steroids might complicate the interpretation of estrogenic bioassay results; thus, their determination will provide invaluable information for use in future studies. The ability to accurately identify endogenous and exogenous estrogens is a major advantage of LC/MS/MS.

\section{CONCLUSIONS}

While this paper details the detection of steroids at environmentally and ecotoxicologically relevant concentrations using mass spectrometric methods it is clear that their analysis in complex marine matrices can continue to present analytical challenges. It is likely that ion suppression due to co-extracted compounds in the sample matrix continues to be a key contributing factor inhibiting successful analysis. Continued lowering of detection limits and the development of costeffective techniques to remove interferences are required to provide greater insight into natural steroid profiles within marine organisms such as Mytilus spp., and to support accurate interpretation of biomarkers of estrogenicity. Filtration of water samples was not found to affect analyte recovery. The developed method was successfully employed for the simultaneous detection of steroid estrogens (E1, E2 and EE2) in water and biota at concentrations above 0.4 to $0.9 \mathrm{ng} / \mathrm{g}$ in biota, and 0.07 to $0.14 \mathrm{ng} / \mathrm{L}$ in sea- water, with $\mathrm{E} 2$ water concentrations being below $0.08 \mathrm{ng} / \mathrm{L}$ which is the proposed WFD 'total water' EQS. The first reported detection of E1 in Dublin Bay and in Irish coastal waters by LC/MS/MS demonstrates that the developed method will prove a valuable tool for ongoing surveillance, and ecotoxicological and environmental monitoring purposes.

\section{Acknowledgements}

This research was funded by Seachange Project, the National Development Plan 2007-2013 Science, Technology \& Innovation Programme and the Environmental Protection Agency, Ireland. Thanks are extended to Dr Iarfhlaidh Connellon for the provision of mussels for this study, to Dublin Port authority for vessel provision and all required permissions to complete this study, to the Galway Mayo Institute of Technology (GMIT) for vessel provision in Galway, and the Galway Harbourmaster for all required permissions. 


\section{REFERENCES}

[1] C. Botham, P. Harrison, P. Holmes, K. Koller, P. Rumbsy. Information exchange and international co-operation on endocrine disruptors. Report for DG Environment, European Commission, IEH Ref. No 3/9/7, 2003.

[2] C. Sonnenschein, A. M. Soto. An updated review of environmental estrogen and androgen mimics and antagonists.

J. Steroid Biochem. Mol. Biol. 1998, 65, 143.

[3] C. Desbrow, E. J. Routledge, G. C. Brighty, J. P. Sumpter, M. Waldock. Identification of estrogenic chemicals in STW effluent. 1. Chemical fractionation and in vitro biological screening. Environ. Sci. Technol. 1998, 32, 1549.

[4] Z-h. Liu, J. A. Ogejo, A. Pruden, K. F. Knowlton. Occurrence, fate and removal of synthetic oral contraceptives (SOCs) in the natural environment: A review. Sci. Total Environ. 2011, 409, 5149.

[5] S. Terzic, I. Senta, M. Ahel, M. Gros, M. Petrovic, D. Barcelo, J. Müller, T. Knepper, I. Martí, F. Ventura, P. Jovancic, D. Jabucar. Occurrence and fate of emerging wastewater contaminants in Western Balkan Region. Sci. Total Environ. 2008, 399, 66.

[6] A. Laganà, A. Bacaloni, I. De Leva, A. Faberi, G. Fago, A. Marino. Analytical methodologies for determining the occurrence of endocrine disrupting chemicals in sewage treatment plants and natural waters. Anal. Chim. Acta 2004, 501,79 .

[7] C. Desbrow, E. J. Routledge, G. C. Brighty, J. P. Sumpter, M. Waldock. Identification of estrogenic chemicals in STW effluent: 1. Chemical fractionation and in vitro biological screening. Environ. Sci. Technol. 1998, 32, 1549.

[8] G. Streck. Chemical and biological analysis of estrogenic, progestagenic and androgenic steroids in the environment. Trends Anal. Chem. 2009, 28, 635.

[9] M. N. Andrew, R. H. Dunstan, W. A. O'Connor, L. Van Zwieten, B. Nixon, G. R. MacFarlane. Effects of 4nonylphenol and 17a-ethynylestradiol exposure in the Sydney rock oyster, Saccostrea glomerata: Vitellogenin induc- tion and gonadal development. Aquat. Toxicol. 2008, 88, 39.

[10] T. J. Pandian, S. G. Sheela. Hormonal induction of sex rever- sal in fish. Aquaculture 1995, 138, 1.

[11] M. Solé, C. Porte, D. Barceló. Analysis of the estrogenic activity of sewage treatment works and receiving waters using vitellogenin induction in fish as a biomarker. Trends Anal. Chem. 2001, 20, 518.

[12] K. A. Kidd, P. J. Blanchfield, K. H. Mills, V. P. Palace, R. E. Evans, J. M. Lazorchak, R. W. Flick. Collapse of a fish population after exposure to a synthetic estrogen. Proc. Natl. Acad. Sci. 2007, 104, 8897.

[13] S. Jobling, D. Casey, T. Rodgers-Gray, J. Oehlmann, U. Schulte-Oehlmann, S. Pawlowski, T. Baunbeck, A. P. Turner, C. R. Tyler. Comparative responses of molluscs and fish to environmental estrogens and an estrogenic effluent. Aquat. Toxicol. 2004, 66, 207.

[14] W. Zhu M. Mantione, D. Jones, E. Salamon, J. J Cho, P. Cadet, G. B. Stefano. The presence of 17-b-estradiol in Mytilus edulis gonadal tissues: Evidence for estradiol isoforms. Neuroendocrinol. Lett. 2003, 24, 137.

[15] A. C. Johnson, A. Belfroid, A. Di Corcia. Estimating steroid oestrogen inputs into activated sludge treatment works and observations on their removal from the effluent. Sci. Total Environ. 2000, 256, 163.

[16] G. D’Ascenzo, A. Di Corcia, A. Gentili, R. Mancini, R. Mastropasqua, M. Nazzari, R. Samperi. Fate of natural estrogen conjugates in municipal sewage transport and treatment facilities. Sci. Total Environ. 2003, 302,199.

[17] M. D. Jürgens, R. J. Williams, A. C. Johnson. Fate and behaviour of steroid oestrogens in rivers: a scoping study. R\&D Technical Report, Environmental Agency, Bristol, 1999, 161.
[18] C. Baronti, R. Curini, G. D'Ascenzo, A. Di Corcia, A. Gentili, R. Samperi. Monitoring natural and synthetic estrogens at activated sludge sewage treatment plants and in a receiving river water. Environ. Sci. Technol. 2000, 34, 5059.

[19] Z-h. Liu, Y. Kanjo, S. Mizutani. Urinary excretion rates of natural estrogens and androgens from humans, and their occurrence and fate in the environment: A review. Sci. Total Environ. 2009, 407, 4975.

[20] W. F. Young, P. Whitehouse, I. Johnson, N. Sorokin. Proposed predicted-no-effect-concentrations (PNECs) for natural and synthetic steroid oestrogens in surface waters. R\&D Technical Report P2-T04/1, Environmental Agency, Bristol, 2004.

[21] H. Noppe, T. Verslycke, E. De Wulf, K. Verheyden, E. Monteyne, P. Van Caeter, C. R. Janssen, H. F. De Brabander. Occurrence of estrogens in the Scheldt estuary: A 2-year survey. Ecotoxicol. Environ. Saf. 2007, 66, 1.

[22] S. Atkinson, M. Atkinson, A. M. Tarrant. Estrogens from sewage in coastal marine environments. Environ. Health Perspect. 2003, 111, 531.

[23] H. Noppe, K. De Wasch, S. Poelmans, N. Van Hoof, T. Verslycke, C. R. Janssen. H. F. De Brabander. Development and valida- tion of an analytical method for the detection of estrogens in water. Anal. Bioanal. Chem. 2005, 382, 91.

[24] V. Gabet, C. Miège, P. Bados, M. Coquery. Analysis of estrogens in environmental matrices. Trends Anal. Chem. 2007, 26, 1113.

[25] T. R. Croley, R. J. Hughes, B. G. Koenig, C. D. Metcalfe, R. E. March. Mass spectrometry applied to the analysis of estrogens in the environment. Rapid Commun. Mass Spectrom. $2000,14,1087$

[26] E. Gosling. The Mussel Mytilus edulis: Ecology, Physiology, Genetics and Culture. Elsevier Science, 1992.

[27] M. A. Reis-Henriques, D. Le Guellec, J. P. Remy-Martin, G. L. Adessi. Studies of endogenous steroids from the mar- ine mollusc Mytilus edulis L. by gas chromatography and mass spectrometry. Comp. Biochem. Physiol. B 1990, 95, 303.

[28] I. Ketata, X. Denier, A. Hamza-Chaffai, C. Minier. Endocrinerelated reproductive effects in molluscs. Comp. Biochem. Physiol. C 2008, 147, 261.

[29] A. David, S. Dagnino, Y. Pichot, D. Munaron, A. Escande, C. Casellas, H. Fenet, E. Gomez. Temporal study of estrogenic reponses of mussel (Mytilus galloprovinciallis) extracts applied to reporter cell lines. Mar. Environ. Res. 2008, 66, 105.

[30] M-H. Dévier, P. Labadie, A. Togola, H. Budzinski. Simple methodology coupling microwave-assisted extraction to SPE/GC/MS for the analysis of natural steroids in biologi- cal tissues: Application to the monitoring of endogenous steroids in marine mussels Mytilus sp. Anal. Chim. Acta 2010, 657, 28.

[31] G. Pojana, A. Gomiero, N. Jonkers, A. Marcomini. Natural and synthetic endocrine disrupting compounds (EDCs) in water, sediment and biota of a coastal lagoon. Environ. Int. 2007, 33, 929.

[32] B. Coghlan, E. Gosling. Genetic structure of hybrid mussel populations in the west of Ireland: two hypotheses revis- ited. Mar. Biol. 2007, 150, 841.

[33] L. Viganò, A. Mandich, E. Benfenati, R. Bertolotti, S. Bottero, E. Porazzi, E. Agradi. Investigating the Estrogenic Risk Along the River Po and Its Intermediate Section. Arch. Environ. Contam. Toxicol. 2006, 51, 641

[34] L. Viganò, E. Benfenati, A. van Cauwenberge, J. K. Eidem, C. Erratico, A. Goksøyr, W. Kloas, S. Maggioni, A. Mandich, R. Urbatzka. Estrogenicity profile and estrogenic com- pounds determined in river sediments by chemical analysis, ELISA and yeast assays. Chemosphere 2008, 73, 1078.

[35] P. Labadie, H. Budzinski. Determination of steroidal hormone profiles along the Jalle d'Eysines River (near Bordeaux, France). Environ. Sci. Technol. 2005, 39, 5113. 
[36] A. Zafra-Gómez, O. Ballesteros, A. Navalón, J. L. Vílchez. Determination of some endocrine disrupter chemicals in urban wastewater samples using liquid chromatography- mass spectrometry. Microchem. J. 2008, 88, 87.

[37] J-B. Baugros, B. Giroud, G. Dessalces, M-F. GrenierLoustalot, C. Cren-Olivé. Multiresidue analytical methods for the ultra-trace quantification of 33 priority substances present in the list of REACH in real water samples. Anal. Chim. Acta 2008, 607, 191

[38] R. Urbatzka, A. van Cauwenberge, S. Maggioni, L. Viganò, A. Mandich, E. Benfenati, I. Lutz, W. Kloas. Androgenic and antiandrogenic activities in water and sediment samples from the river Lambro, Italy, detected by yeast androgen screen and chemical analyses. Chemosphere 2007, 67, 1080.

[39] M. J. Gomez, M. Petrovic, A. R. Fernández-Alba, D. Barceló. Determination of pharmaceuticals of various therapeutic classes by solid-phase extraction and liquid chromatogra- phy tandem mass spectrometry analysis in hospital effluent wastewaters. J. Chromatogr. A 2006, 1114, 224.

[40] H-S. Chang, K-H. Choo, B. Lee, S-J. Choi. The methods of identification, analysis, and removal of endocrine disrupt- ing compounds (EDCs) in water. J. Hazard. Mater. 2009, 172, 1.

[41] Waters Corporation. Endocrine Disruptors - General SPE Guidelines. Waters Oasis Sample Extraction Products, 2003, p. 73. www.waters.com

[42] Waters Corporation. SPE Methodology - Section 1: Oasis Generic Methodology. Waters Oasis Sample Extraction Products, 2003, p. 15. www.waters.com.

[43] C. Miège, P. Bados, C. Brosse, M. Coquery. Method valida- tion for the analysis of estrogens (including conjugated com- pounds) in aqueous matrices. Trends Anal. Chem. 2009, 28, 237.

[44] M. Dobrynin, G. Gayer, A. Pleskachevsky, H. Günther. Effect of waves and currents on the dynamics and seasonal variations of suspended particulate matter in the North Sea. J. Mar. Syst. 2010, $82,1$.

[45] F. E. Anderson, L. M. Meyer. The interaction of tidal currents on a disturbed intertidal bottom with a resulting change in particulate matter quantity, texture and food quality. Estuar. Coast. Shelf Sci. 1986, 22, 19.

[46] G. M. Ferraria, F. G. Boa, M. Babinb. Geo-chemical and optical characterizations of suspended matter in European coastal waters. Estuar. Coast. Shelf Sci. 2003, 57, 17.

[47] J. C. Bowman, J. L. Zhou, J. W. Readman. Sediment-water interactions of natural oestrogens under estuarine condi- tions. Mar. Chem. 2002, 77, 263.

[48] C. M. Ciocan, E. Cubero-Leon, A. M. Puinean, E. M. Hill, C. Minier, M. Osada, K. Fenlon, J. M. Rotchell. Effects of estrogen exposure in mussels, Mytilus edulis, at different stages of gametogenesis. Environ. Pollut. 2010, 158, 2977.

[49] K. Van den Belt, P. Berckmans, C. Vangenechten, R. Verheyen, H. Witters. Comparative study on the in vitro/in vivo estro- genic potencies of 17b-estradiol, estrone, 17a-ethynylestradiol and nonylphenol. Aquat. Toxicol. 2004, 66, 183.

[50] M. J. López de Alda, D. Barceló. Use of solid-phase extrac- tion in various of its modalities for sample preparation in the determination of estrogens and progestogens in sediment and water. J. Chromatogr. A 2001, 938, 145.

[51] R. J. Williams, A. C. Johnson, J. J. L. Smith, R. Kanda. Steroid estrogens profiles along river stretches arising from sewage treatment works discharges. Environ. Sci. Technol. 2008, 37, 1744.

[52] H. Tarrant, N. Llewellyn, A. Lyons, N. Tattersall, S. Wylde, G. Moutakitis, M. Maloney, C. McKenzie. Endocrine Disruptors in the Irish Aquatic Environment - Final Report. Environmental Protection Agency, Ireland, 2005.

[53] H. R. Andersen J. Kjølholt, M. Hansen, F. Stuer-Lauridsen, T. Dueholm Blicher, F. Ingerslev, B. Halling-Sørensen. Degradation of Estrogens in Sewage Treatment Processes, Danish Environment Protection Agency, 2004.

[54] M. D. Jürgens, K. I. E. Holthaus, A. C. Johnson, J. J. L. Smith, M. Hetheridge, R. J. Williams. The potential for estradiol and ethinylestradiol degradation in English rivers. Environ. Toxicol. Chem. 2002, 21, 480.

[55] M-L. Janex-Habibi, A. Huyard, M. Esperanza, A. Bruchet. Reduction of endocrine disruptor emissions in the environ- ment: The benefit of wastewater treatment. Water Res. 2009, 43, 1565.

[56] V. Gabet-Giraud, C. Miége, J. M. Choubert, S. M. Ruel, M. Coquery. Occurrence and removal of estrogens and beta blockers by various processes in wastewater treatment plants. Sci. Total Environ. 2010, 408, 4257.

[57] R. J. Williams, A. C. Johnson, J. J. L. Smith, R. Kanda. Steroid estrogens profiles along river stretches arising from sewage treatment works discharges. Environ. Sci. Technol. 2003, 37, 1744.

[58] G. Saravanabhavan, R. Helleur, J. Hellou. GC-MS/MS measurement of natural and synthetic estrogens in receiving waters and mussels close to a raw sewage ocean outfall. Chemosphere 2009, 76, 1156.

[59] M. Giltrap, A. Macken, M. Davoren, D. Minchin, E. McGovern, B. Foley, J. Strand, B. McHugh. Use of caged Nucella lapillus and Crassostra gigas to monitor tributyltininduced bioeffects in Irish coastal waters. Environ. Sci. Technol. 2009, 28, 1671.

[60] M. Giltrap, A. Macken, M. Davoren, E. McGovern, B. Foley, M. Larsen, J. White, B. McHugh. Utilising caging techniques to investigate metal assimilation in Nucella lapillus, Mytilus edulis and Crassostrea gigas at three Irish coastal locations. Estuar. Coast. Shelf Sci. 2013, in press. DOI: 10.1016/j. ecss.2011.11.040.

[61] G. Janer, C. Porte. Sex steroids and potential mechanisms of non genomic endocrine disruption in invertebrates. Ecotoxicol- ogy 2007, 16, 145.

[62] R. Lavado, G. Janer, C. Porte. Steroid levels and steroid metabolism in the mussel Mytilus edulis: The modulating effect of dispersed crude oil and alkylphenols. Aquat. Toxicol. 2006, 78, S65.

[63] M. Gust, E. Vulliet, B. Giroud, F. Garnier, S. Couturier, J. Garric, T. Buronfosse. Development, validation and comparison of LCMS/MS and RIA methods for quantifica- tion of vertebrates-like sex-steroids in prosobranch molluscs. $J$. Chromatogr. B 2010, 878, 1487. 